\title{
Cellular and Humoral Sensitivity to Gluten Fractions in Patients With Treated Nontropical Sprue
}

\author{
Joel Morganroth," BS, David W. Watson, $†$ MD and Arthur B. French, MD
}

The presence of circulating antibodies and lymphocyte response to gliadin and fraction III were measured in three groups of 12 patients each. Group I consisted of patients with nontropical sprue maintained on a gluten-free diet; Group II contained patients with other gastrointestinal diseases manifesting malabsorption and Group III was composed of normal controls. Rabbits immunized to both antigens provided positive controls for each method of antibody determination. Results agree with those previously reported in that negligible antibody titers were present to either antigen in normals, patients with other forms of malabsorption or patients with nontropical sprue maintained, for some time, on a glutenfree diet. Lymphocyte stimulation failed to occur with either gluten fraction although the hyporesponsiveness to phytohemagglutinin, previously reported by others, was not observed. Further studies are needed in patients with nontropical sprue following controlled antigenic challenge. Antibody levels in jejunal fluid should also be studied. Until such studies are carried out, evaluation of immunologic factors in the pathogenesis of nontropical sprue will be incomplete.

Although gluten sensitivity is a fundamental abnormality in patients with nontropical sprue, its relationship to other pathophysiologic phenomena remains obscure. In most patients, abstention from all gluten products produces a dramatic improvement in clinical symptoms and often nearly reverses the mucosal abnormality. Even after seemingly total clinical remission, challenge with gluten or, more spe-

From the Department of Internal Medicine, Gastroenterology Section, The University of Michigan Medical School, Ann Arbor, Mich.

Supported by Grants FR-42 from the Division of Research Facilities and Resources; AM-07120 and 10213 from the National Institute for Arthritis and Metabolic Diseases, US Public Health Service.

Address for reprint requests: Arthur B. French, MD, Department of Internal Medicine, University of Michigan Medical School, Ann Arbor, Mich 48104

*Present address: Beth Israel Hospital, 330 Brookline, Boston, Mass 02215

tPresent address: Department of Medicine, University of Catifornia, Davis, Calif. cifically, one of its fractions such as gliadin or the pepsin-trypsin digest, called Fraction III by Frazer (1), aggravates the disease.

Attempts to explain this deleterious effect of cereal proteins have produced 2 hypotheses. One postulates a specific enzymatic defect in the intestinal mucosal cell, which results in the accumulation of peptides that may be directly toxic to the intestinal epithelium; the other invokes a primary hypersensitivity response to gluten or one of its fractions. Recent investigations (2-5) of circulating antibodies to Fraction III and to milk proteins in patients with nontropical sprue have stressed the possible immunologic nature of this disorder. Meaningful comparison between different studies is diffcult, however, because frequently the patient population studied is not homogeneous and the sensitivity of different immunologic assays varies. Only one published report deals with delayed hypersensitivity to gluten fractions (6). 
The purpose of this study was to investigate circulating antibodies and cellular hypersensitivity to gliadin and Fraction III by several different methods in patients with nontropical sprue who had been maintained on a glutenfree diet.

\section{MATERIALS AND METHODS}

Subjects. Thirty-six subjects represented 3 experimental groups of 12 patients each. Group 1 consisted of patients with nontropical sprue. Diagnoses in 10 were based on characteristic clinical, radiographic and histologic abnormalities. These patients had responded well to a glutenfree diet for 3-10 years. The other 2 patients had clinical manifestations of sprue, but biopsies were not diagnostic. Both had responded well to gluten-free diets for 4 years. Group 2 was composed of patients with other gastrointestinal disorders; most manifested some form of malabsorption. Included in this group were patients with postgastrectomy steatorrhea, fibrocystic disease, short-bowel syndrome, ulcerative colitis and blind-loop syndrome. Group 3 consisted of healthy adults with no evidence of gastrointestinal disturbance. Blood samples were obtained from each subject. Clotted blood was the source of serum for antibody determinations and heparinized blood for the lymphocytes for lymphocyte stimulation studies.

Antigens. The fractions of wheat gluten used as antigens for these studies were an aqueous solution of gliadin and a pepsin-trypsin digest of gliadin similar to fraction III of Frazer (1). The aqueous solution of gliadin was prepared as follows: $20 \mathrm{~g}$ of purified gluten (Nutritional Biochemicals Corporation, Cleveland) were dissolved in $70 \%$ ethanol and the solution dialyzed against tap water. The resulting precipitate was stirred with $150 \mathrm{ml}$ of deionized water for 60 minutes. The supernatant aqueous solution of gliadin, containing $1 \mathrm{mg}$ protein $/ \mathrm{ml}$ was used as the gliadin antigen.

The pepsin-trypsin digest of gliadin was prepared as follows: $8 \mathrm{ml}$ of the aqueous solution of gliadin, adjusted to $\mathrm{pH}$ 2.0 , was added to $4 \mathrm{ml}$ of a $2 \%$ pepsin solution adjusted to pH 3.0 (pepsin, 1:15,000 activity, Mann Research Laboratories, New York). After 3 hours of stirring, the $\mathrm{pH}$ was adjusted to 7.0 , and $100 \mathrm{mg} \mathrm{of} \mathrm{NaCl}$ and $5 \mathrm{ml}$ of $2 \%$ trypsin solution were added. The $\mathrm{pH}$ was then adjusted to 8.0 and the solution stirred for an additional 3 hours. The protein concentration of this mixture, as determined by UV spectrophotometry, was $2 \mathrm{mg} / \mathrm{ml}$.

Tests for Humoral Antibodies. Circulating antibody titers were determined by three methods: a) Ouchterlony double gel diffusion (7); b) passive cutaneous anaphylaxis (8) and c) hemagglutination (9).
Double gel diffusion. Diffusion was carried out by the microscopic slide technic in $2 \%$ agar* containing $0.9 \%$ $\mathrm{NaCl}$. Both gliadin and Fraction III were tested against undiluted sera. Plates were run overnight in duplicate and the results read only as positive or negative

Hemagglutination. Tanned sheep cells ${ }^{\dagger}$ were sensitized with Fraction III and added to serial twofold dilutions of sera. Tests were carried out in duplicate and the results read after 2 and 24 hours of incubation. Gliadin could not be used as an antigen in this procedure because it caused spontaneous agglutination of the sheep cells over wide ranges of concentration and $\mathrm{pH}$.

Passive cutaneous anaphylaxis. Ovary's method was modified as follows: male Hartly guinea pigs (minimum weight, $500 \mathrm{~g}$ ) were injected intradermally with diluted $(1: 20$ in $0.9 \% \mathrm{NaCl})$ and undiluted sera on the shaved abdomen under ether anesthesia. After $4-6$ hours, intracardiac injections of $1.0 \mathrm{ml}$ of $0.5 \%$ Evans blue-dye solution $\neq$ and $1.0 \mathrm{ml}$ of gliadin solution were given. After 30 minutes, the animals were sacrificed and the intradermal injection sites were compared with the untraumatized inner aspect of abdominal skin. The tests were run in duplicate and recorded only as positive or negative.

\section{Controls for Humoral Antibody Determinations.} Negative controls for all 3 technics consisted of $0.9 \%$ $\mathrm{NaCl}$ in place of the patient's serum. Positive controls were obtained by immunizing male New Zealand white rabbits with $10 \mathrm{ml}$ of a $1: 1$ emulsion of aqueous gliadin extract and Freund's complete adjurant (Difco. Detroit). In the double gel diffusion test, rabbit sera produced precipitin lines against gliadin extract but not against Fraction III, possibly because the molecular weights of its constituent peptides were low. When rabbit antiserum was adsorbed with an equal volume of gliadin extract, the precipitin lines were completely inhibited but adsorption with Fraction 111 only caused diminutions in their intensities. Rabbit antigliadin antiserum was also used as a positive control in hemagglutination against Fraction III as antigen. Positive titers ranging from 1:128 to 1:2048 were obtained, the titer depending on the animal and date of bleeding. In the passive cutaneous anaphylaxis procedure, antigliadin sera gave uniformly positive results with both gliadin and Fraction III.

\section{The Evaluation of Delayed Hypersensitivity}

Lymphocyte transformation was used as an in vitro correlate of delayed hypersensitivity. The criteria established

* Purified agar, Difco, Detroit, Mich.

+ Baltimore Biological Laboratories, Baltimore, Md.

† University Hospital Pharmacy, Ann Arbor. Mich. 
by Mills (10) to distinguish transformed cells were followed. The technic was as follows: 30 to $75 \mathrm{ml}$ of heparinized blood * with approximately 1000 LSP units of heparin per $25 \mathrm{ml}$ was sedimented at $37^{\circ} \mathrm{C}$ for $1-2$ hours. The plasma was aspirated and centrifuged at $271 \mathrm{~g}$ for 5 minutes. The cell button was resuspended in $1 \mathrm{ml}$ of the supernatant plasma, transferred to a $1-\mathrm{ml}$ Wintrobe hematocrit tube and centrifuged at $81 \mathrm{~g}$ for 5 minutes. The supernatant plasma was removed and centrifuged at $271 \mathrm{~g}$ for $5 \mathrm{~min}$ utes. The resulting cell button, containing at least $90 \%$ lymphocytes, was resuspended in Eagle's minimum essential medium with Hanks balanced salts containing $15 \% \mathrm{fe}-$ tal calf serum, $2.92 \mathrm{~g} / 100 \mathrm{ml}$ of L-glutamine, 500 units of penicillin and $500 \mu \mathrm{g}$ of streptomycin $/ \mathrm{ml}$. The final cell concentration was $3 \times 10^{6}$ cells $/ \mathrm{ml}$. Viability was virtually $100 \%$ as determined by dye exclusion (erythrosin B). Incubations were carried cut at $37^{\circ} \mathrm{C}$ in $2-\mathrm{ml}$ aliquots in glass culture tubes $(100 \mathrm{~mm} \times 15 \mathrm{~mm})$ with screw plastic caps. The cells were harvested and resuspended in $0.25 \mathrm{ml}$ of a 3:1 solution of methanol and glacial acetic acid. Coverslip smears were made, air dried and stained with $0.5 \%$ acetoorcein.

The lymphocyte suspensions from each subject were divided into 4 aliquots. To each $2-\mathrm{ml}$ aliquot was added either $0.1 \mathrm{ml}$ of culture media, $0.1 \mathrm{ml}$ of the Fraction III solution, $0.1 \mathrm{ml}$ of gliadin solution or $0.1 \mathrm{ml}$ of phytohemagglutinin ${ }^{+}$.

\section{Controls of Determinations for Delayed Hypersensitivity}

To show that lymphocyte transformation could correlate with cutaneous delayed hypersensitivity to gluten fractions, lymphocytes from New Zealand white rabbits immunized with gliadin and Freund's complete adjuvant were tested in the same manner. Rabbits used as positive controls consistently exhibited both delayed cutaneous reactions to $0.1 \mathrm{ml}$ of gliadin solution when injected intradermally and transformation of 27 to $53 \%$ of lymphocytes when exposed to gliadin.

\section{RESULTS}

\section{Humoral Antibody Studies}

Double gel diffusion and passive cutaneous anaphylaxis failed to demonstrate antibodies to either gliadin or Fraction III in any of the experimental groups. Serum from immunized rabbits on every occasion gave strong positive reactions to gliadin, using either double gel

\footnotetext{
* Liquaemin sodium 10, Organon Corp, West Orange, NJ.

+ PHA-M, Difco, Detroit, Mich.
}

diffusion or passive cutaneous anaphylaxis and to Fraction III, using passive cutaneous anaphylaxis.

Hemagglutination titers to Fraction III were not significantly different in the three experimental groups. In patients with nontropical sprue, titers ranged from 0 to $1: 16$ with $67 \%$ above $1: 4$. In patients with other gastrointestinal disorders, titers ranged from 0 to $1: 16$ with $42 \%$ above $1: 4$. In the normal subjects, titers ranged from 0 to $1: 32$ with $67 \%$ above $1: 4$. Rabbit antisera consistently gave titers ranging from $1: 128$ to $1: 2048$.

\section{Lymphocyte Transformation}

There was no significant difference in lymphocyte response to either gliadin or Fraction III in the three experimental groups. The mean transformation in response to gliadin was $5 \%$ for patients with nontropical sprue, $8 \%$ for patients with other gastrointestinal disorders and $5 \%$ for the normal control subjects. Mean transformations for the Fraction III cultures were $7 \%$ for the patients with nontropical sprue, $5 \%$ for the gastrointestinal control group and $5 \%$ for the normal controls.

Cultures without antigen produced transformations ranging between 0 and $14 \%$ at both 3- and 6-day intervals while cultures containing phytohemagglutinin (PHA) responded with transformations ranging between 50 and $84 \%$ after 3 days. These values are somewhat higher than the usual controls and may represent a slight response to the fetal calf serum. The rabbit controls showed transformations of $27 \%$ to Fraction III and 53\% to gliadin at 6 days. Mean transformation for control cultures from patients was $5 \%$ at 6 days and those for PHA, $66 \%$ at 3 days. Mean transformation for rabbit control cultures was $3 \%$ at 6 days and $82 \%$ for PHA cultures at 3 days.

In summary, there was no significant difference in circulating antibody titers to either antigen in the three experimental groups and there was no evidence of delayed hypersensi- 
Table 1. Group I. Patients with Nontropical Sprue Maintained on a Gluten-Free Diet

\begin{tabular}{|c|c|c|c|c|c|c|c|c|c|c|c|}
\hline \multirow[b]{2}{*}{$\begin{array}{c}\text { Patient } \\
\text { No. }\end{array}$} & \multirow[b]{2}{*}{$\begin{array}{l}\text { Age/ } \\
\text { sex }\end{array}$} & \multirow[b]{2}{*}{$\begin{array}{c}\text { SB } \\
\text { biopsy }\end{array}$} & \multirow[b]{2}{*}{$\begin{array}{l}\text { GFD } \\
\text { (yrs) }\end{array}$} & \multirow[b]{2}{*}{ DGD } & \multirow[b]{2}{*}{ PCA } & \multirow[b]{2}{*}{ HAGG } & \multicolumn{2}{|c|}{ LT-3 days } & \multicolumn{3}{|c|}{ LT-6 days } \\
\hline & & & & & & & $\mathrm{C}$ & PHA & $\mathrm{C}$ & G1 & $\begin{array}{c}\text { Fraction } \\
\text { III }\end{array}$ \\
\hline 005 & $72 \mathrm{~F}$ & + & 6 & $\mathrm{Neg}$ & $\mathrm{Neg}$ & $1: 8$ & 11 & 58 & 9 & 10 & 5 \\
\hline 013 & $17 \mathrm{M}$ & $t$ & 3 & $\mathrm{Neg}$ & $\mathrm{Neg}$ & 0 & 7 & 62 & 1 & 8 & 6 \\
\hline 016 & $57 \mathrm{~F}$ & + & 10 & Neg & Neg & $1: 4$ & 9 & 78 & 6 & 3 & 9 \\
\hline 018 & $32 F$ & - & 4 & $\mathrm{Neg}$ & Neg & $1: 8$ & 2 & 73 & 10 & 4 & 10 \\
\hline 023 & $63 \mathrm{~F}$ & + & 9 & Neg & Neg & $1: 8$ & 4 & 61 & 3 & 5 & 6 \\
\hline 028 & $61 \mathrm{~F}$ & + & 8 & Neg & Neg & $1: 16$ & 11 & 62 & 3 & 2 & 7 \\
\hline 029 & $36 \mathrm{~F}$ & + & 4 & $\mathrm{Neg}$ & $\mathrm{Neg}$ & $1: 4$ & 6 & 59 & 5 & 2 & 10 \\
\hline 030 & $61 \mathrm{~F}$ & + & 9 & Neg & $\mathrm{Neg}$ & $1: 2$ & 2 & 82 & 7 & 12 & 4 \\
\hline 031 & $55 \mathrm{~F}$ & + & 7 & Neg & Neg & $1: 2$ & 5 & 69 & 3 & 8 & 12 \\
\hline 032 & $50 F$ & + & 7 & Neg & Neg & $1: 2$ & 1 & 68 & 2 & 2 & 8 \\
\hline 034 & $55 \mathrm{~F}$ & + & 6 & $\mathrm{Neg}$ & $\mathrm{Neg}$ & $1: 2$ & 10 & 71 & 4 & 7 & 5 \\
\hline 035 & $20 \mathrm{M}$ & - & 4 & $\mathrm{Neg}$ & Neg & $1: 8$ & 3 & 62 & 2 & 5 & 6 \\
\hline
\end{tabular}

GFD = gluten-free diet; $D G D=$ double gel diffusion; PCA = passive cutaneous anaphylaxis; HAGG = hemagglutination: $\mathrm{C}=$ control; $\mathrm{PHA}=$ phytohemagglutinin; $\mathrm{G} 1=$ gliadin; $\mathrm{LT}=$ lymphocyte transformation.

tivity to gliadin or Fraction III in any of the patients as assessed by lymphocyte stimulation.

These results are summarized in Tables $1-3$.

\section{DISCUSSION}

Two general hypotheses have developed to explain gluten sensitivity in patients with non- tropical sprue. One postulates a peptidase deficiency in the intestinal mucosal cell; this deficiency results in an accumulation of peptides which might have a direct toxic effect upon the epithelium. The other hypothesis invokes a state of hypersensitivity in which the antigenic determinants of gluten are involved in some form of immunologic reaction which results in

Table 2. Group II. Patients with Gastrointestinal Disease

\begin{tabular}{|c|c|c|c|c|c|c|c|c|c|c|}
\hline \multirow[b]{2}{*}{$\begin{array}{l}\text { Patient } \\
\text { No. }\end{array}$} & \multirow[b]{2}{*}{$\begin{array}{l}\text { Age/ } \\
\text { sex }\end{array}$} & \multirow[b]{2}{*}{ Diagnosis } & \multirow[b]{2}{*}{ DGD } & \multirow[b]{2}{*}{$\mathrm{PCA}$} & \multirow[b]{2}{*}{ HAGG } & \multicolumn{2}{|c|}{ LT-3 days } & \multicolumn{3}{|c|}{ LT-6 days } \\
\hline & & & & & & C & PHA & C & Gl & $\begin{array}{c}\text { Fraction } \\
\text { III }\end{array}$ \\
\hline 001 & $28 \mathrm{~F}$ & Jejunoileostomy & Neg & Neg & $1: 2$ & - & - & 6 & 5 & 7 \\
\hline 002 & $43 \mathrm{~F}$ & SB resection & Neg & Neg & 0 & - & - & 12 & 11 & 2 \\
\hline 003 & $68 \mathrm{~F}$ & Postgastrectomy & Neg & Neg & 0 & - & - & 11 & 14 & 10 \\
\hline 004 & $36 \mathrm{M}$ & SB resection & Neg & Neg & 0 & - & - & 12 & 12 & 9 \\
\hline 011 & $59 \mathrm{~F}$ & Postgastrectomy & Neg & $\mathrm{Neg}$ & $1: 2$ & 2 & 65 & 2 & 1 & 3 \\
\hline 020 & $49 M$ & Malabsorption & Neg & Neg & $1: 8$ & 6 & 68 & 5 & 3 & 2 \\
\hline 024 & $31 \mathrm{~F}$ & Postgastrectomy & Neg & Neg & $1: 16$ & 3 & 52 & 4 & 3 & 1 \\
\hline 025 & $13 \mathrm{M}$ & Fibrocystic disease & $\mathrm{Neg}$ & Neg & $1: 4$ & 8 & 76 & 7 & 10 & 5 \\
\hline 026 & $16 \mathrm{M}$ & Fibrocystic disease & Neg & Neg & $1: 16$ & 8 & 62 & 10 & 11 & 15 \\
\hline 033 & $28 \mathrm{~F}$ & Ulcerative colitis & Neg & Neg & $1: 4$ & 4 & 78 & 5 & 1 & 2 \\
\hline 036 & $24 \mathrm{M}$ & Ulcerative colitis & $\mathrm{Neg}$ & Neg & 0 & 9 & 72 & 4 & 2 & 7 \\
\hline 014 & $50 \mathrm{M}$ & Postgastrectomy & Neg & $\mathrm{Neg}$ & 0 & 8 & 84 & 10 & 7 & 2 \\
\hline
\end{tabular}


Table 3. Group III. Normal Controls

\begin{tabular}{|c|c|c|c|c|c|c|c|c|c|}
\hline \multirow[b]{2}{*}{$\begin{array}{c}\text { Patient } \\
\text { No. }\end{array}$} & \multirow[b]{2}{*}{ Age/sex } & \multirow[b]{2}{*}{ DGD } & \multirow[b]{2}{*}{ PCA } & \multirow[b]{2}{*}{ HAGG } & \multicolumn{2}{|c|}{ LT-3 days } & \multicolumn{3}{|c|}{ LT 6 days } \\
\hline & & & & & C & PHA & C & Gl & $\begin{array}{c}\text { Fraction } \\
\text { III }\end{array}$ \\
\hline 006 & $24 \mathrm{~F}$ & Neg & Neg & $1: 4$ & 14 & 46 & 12 & 4 & 8 \\
\hline 007 & $27 \mathrm{~F}$ & Neg & $\mathrm{Neg}$ & $1: 16$ & 12 & 50 & 7 & 10 & 4 \\
\hline 008 & $23 \mathrm{~F}$ & Neg & Neg & $1: 2$ & 11 & 63 & 4 & 16 & 10 \\
\hline 009 & $30 M$ & Neg & Neg & 0 & 3 & 74 & 8 & 6 & 5 \\
\hline 010 & $37 \mathrm{~F}$ & Neg & Neg & $1: 2$ & 7 & - & 2 & 3 & 3 \\
\hline 012 & $25 \mathrm{M}$ & Neg & Neg & 0 & 1 & 68 & 4 & 6 & 1 \\
\hline 015 & $26 \mathrm{~F}$ & $\mathrm{Neg}$ & Neg & $1: 4$ & 2 & 75 & 1 & 4 & 2 \\
\hline 017 & $64 M$ & $\mathrm{Neg}$ & Neg & 0 & 5 & 66 & 4 & 0 & 6 \\
\hline 019 & $31 \mathrm{M}$ & Neg & Neg & $1: 16$ & 8 & 74 & 8 & 5 & 3 \\
\hline 021 & $21 \mathrm{M}$ & $\mathrm{Neg}$ & Neg & $1: 4$ & 3 & 50 & 2 & 4 & - \\
\hline 022 & $20 \mathrm{M}$ & $\mathrm{Neg}$ & Neg & $1: 2$ & 4 & 55 & 2 & 3 & 6 \\
\hline 027 & $23 \mathrm{M}$ & $\mathrm{Neg}$ & Neg & $1: 32$ & 1 & 50 & 1 & 3 & 5 \\
\hline
\end{tabular}

the characteristic histologic and functional changes.

Enzymatic defects of the intestinal mucosal cell have been shown in the case of disaccharidases (11), both as an isolated defect in congenital disaccharidase deficiency and, presumably, as part of a more general mucosal cell in nontropical sprue. However, there was no clear evidence of a peptidase deficiency in the small intestine of patients with nontropical sprue. Messer and co-workers (12) have demonstrated normal levels of some peptidases in the small intestine of patients with celiac disease, finding normal rates of hydrolysis for certain di- and tripeptides. This does not eliminate the possibility that the patient with nontropical sprue lacks an hydrolytic enzyme for a more complex peptide. Multidimensional digestion maps of gliadin peptides, (13) have demonstrated that the mucosa from patients with nontropical sprue digests gliadin peptides differently than do guinea pig and normal human mucosa. A rise in peptide-bound glutamine in the blood of patients with sprue, after gliadin loading has also been interpreted by Weijers (14) and Alvey (15) as evidence of a mucosal enzyme defect. The possibility of a primary proteolytic enzyme defect in patients with sprue requires further investigation.

Similarly, several clinical and experimental observations have been cited to support an immune basis for this disorder. Among these are the observations of Krainich et al (16), who reported "gluten shock" in a few patients fed minute quantities of gliadin. Although we have administered gluten challenges at the level of 10 $\mathrm{g}$ of grain protein/day to more than a dozen patients, we have never seen an acute shock-like response to gluten feeding or tube feeding. Although intestinal absorption of sugar may be changed, measurably, within hours after gluten has been administered, it is usually several days before gastrointestinal symptoms are prominent (17). The presence of an increased number of eosinophils in the stools of patients with sprue, the increase in plasma cells and lymphocytes in the lamina propria and the occasional benefit from corticosteroids are suggestive of an immune response (18). However, all of these observations are highly circumstantial and their interpretations can vary.

Circulating antibody titers to gluten fractions are difficult to interpret. Sensitivity varies from method to method and from one laboratory to 
Table 4. Patients with Nontropical Sprue

\begin{tabular}{lcl}
\hline & Positive DGD $(\%)$ & \multicolumn{1}{c}{ Positive HAGG to wheat fractions } \\
\hline Regular diet & $18^{24} \cdot 0^{2}$ & $88^{24}(\geq 1: 64), 100^{2}(\geq 1: 200)$ \\
Gluten-free diet & $23^{19} \cdot 0^{24}, 0^{*}$ & $6^{24}(\geq 1: 64), 56^{2}(\geq 1: 200), 8^{*}(\geq 1: 16)$ \\
Diet unknown & $35^{3} \cdot 0^{4}$ & $0^{4}(\geq 1: 1000)$ \\
\hline
\end{tabular}

Numbers expressed to nearest whole percentage

Summary comparison of present data on patient with nontropical sprue with results in literature :Present study

another. Negative controls are necessary to establish the level of reactivity of the general population. In our studies, neither the general population nor the patients with sprue showed positive reactions. Positive controls are required to demonstrate reactivity and specificity of the system. With all of the methods used in our studies, sera of immunized rabbits gave positive reactions to gliadin and to Fraction III. In many of the reported studies both positive and negative controls were not used. Data from some representative studies are listed in Table 4. Our results are in general agreement with those of Taylor (2), Sewell (4) and AlarconSegovia (5) with whose studies ours can be most nearly compared. However, in their studies, patients on gluten-free diet did not consistently show a lack of significant antibodies to wheat protein. All of our patients with nontropical sprue had been on a gluten-free diet long enough to produce clinical remission and none showed significant antibody titers. Evidently, our results were influenced by gluten ingestion and by the assay method, but they did not correlate well with clinical or histologic activity. It should be emphasized that a correlation with gluten ingestion is not necessarily the same as a relation to the disease activity or clinical symptoms. It is also not possible to compare the studies which use gliadin with those employing Fraction III as an antigen. Fraction III is a poorly characterized mixture of peptides and enzymes of gastric and pancreatic origin; variations in composition from time to time and study to study must inevitably complicate the interpretation of results. Furthermore, different immunologic technics, having different modes of expression and levels of sensitivity, do not form suitable bases for comparison. It is doubtful, therefore, that critical studies of antibody formation can be carried out until the antigenic determinants of gluten are purified and better characterized, and studies utilizing such antigens with uniform and sensitive assay technics are carried out in clearly defined patients subjected to controlled antigenic challenge. Patients with significant titers of antibodies to gluten fractions also frequently have antibodies to milk proteins $(2-5,19)$. This has been considered evidence of a secondary origin for these antibodies and evidence that peptides of grain or milk proteins pass through the abnormal mucosa and, therefore, have access to antibody-forming tissues.

Levels of all major classes of serum immunoglobulins ( $\operatorname{IgG}, \operatorname{Ig} \mathrm{M}, \operatorname{Ig} \mathrm{A}, \operatorname{IgD}$, and $\lg \mathrm{E}$ ) have been determined in patients with nontropical sprue (20-23). Modest increases in serum Ig.1 levels are sometimes present. In one study (20), the elevated IgA levels decreased when the gluten-free diet was started. Concentrations of IgG, IgD and IgE have not differed significantly from controls. IgM levels have been reported decreased in approximately one-third of patients with sprue and in one study (19). they rose when gluten was eliminated.

The distribution of immunoglobulincontaining cells in the intestinal mucosa and levels of immunoglobulin in intestinal fluid have also been studied $(24,25)$. The cellular 
distribution of $\operatorname{Ig} \Lambda, \operatorname{Ig} G, \operatorname{Ig} D$ and $\operatorname{IgE}$ has not differed from normal individuals, nor has their concentrations in intestinal fluid. IgM levels in jejunal fluid as well as Ig.M-containing cells in the jejunal mucosa were increased in all 22 patients studied by Hobbs et al (22), who stated that this abnormality was confined to the jejunum.

Little has been done to investigate the possible role of cellular (delayed) hypersensitivity in nontropical sprue. Impaired lymphocyte stimulation by PHA has been reported by Bletcher (23). This has been considered by Huizenga (26) as but one manifestation of a more generalized lymphoreticular dysfunction which also includes hypogamimaglobulinemia, splenic atrophy (27) and a predilection to develop lymphomas $(28,29)$. Only one other study of lymphocyte response to gluten fractions has been published (6). Housley and co-workers examined the peripheral blood lymphocyte response to Fraction III in 6 patients with adult celiac disease and found no stimulation. Modest stimulation did occur with lymphocytes from mesenteric nodes in 2 patients. This led the authors to consider the possibility of a local form of delayed hypersensitivity to gluten fractions, an explanation that seems unlikely because an isolated population of lymphocytes confined to the intestine and its regional nodes has not been demonstrated, and delayed hypersensitivity reactions which have been induced in the intestine have found systemic expression.

Although our results do not differ from those of most previous studies, the aforementioned criticisms have been largely avoided. All the patients had been on gluten-free diets for substantial periods of time; positive controls were included; three different technics for determining antibody titers were simultaneously employed; both gliadin and Fraction III were used as antigens and delayed hypersensitivity was investigated concurrently in the same patients.

The next logical step would be to study the same patients by the same technics but to extend the studies to include intestinal secretions after a challenge with known amounts of gluten fractions. The antibody titers and lymphocyte response could then be correlated with functional and histologic changes. With respect to antibodies in intestinal fluid, it would be important to use a method that has a greater specificity and sensitivity than double gel diffusion, such as a radioimmunossay technic. To date, we have not been able to prepare a properly labeled gluten fraction suitable for use as an antigen.

Until such studies are carried out, little can be concluded about the possible role of immune responses to gluten fractions in the pathogenesis of nontropical sprue. Even then, the answer may not be forthcoming.

\section{REFERENCES}

1. Frazer AC, Fletcher RF, Ross CAC, et al: Gluten induced enteropathy. The effect of partially digested gluten. Lancet 2:252-255, 1959

2. Taylor KB, Thomson DL, Truelove SC, et al: An immunological study of coeliac disease and idiopathic steatorrhea. $\mathrm{Br} \mathrm{J}$ 2:1727-1731, 1961

3. Heiner DC, Lahey ME, Wilson JF, et al: Precipitens to antigens of wheat and cow milk. J Pediat 61:813-830, 1962

4. Sewell P, Cooke WT, Cox, EV, et al: Milk intolerance in gastrointestinal disorders. Lancet 2:1132-1135, 1963

5. Alarcon-Segovia D, Herskovic T, Wakim KG, et al: Presence of circulating antibodies to gluten and milk fractions in patients with nontropical sprue. Am J Med 36:485-499, 1964

6. Housley J, Asquith P, Cooke WT: Immune response to gluten in coeliac disease. $\mathrm{Br}$ Med $\mathrm{J}$ 1:159-161,1969

7. Ouchterlony $\mathrm{O}:$ In vitro method for testing the toxin producing capacity of diphtheria bacteria. Acta Pathol Microbiol Scand 25:186-191, 1948

8. Ovary $\mathrm{Z}$ : Immediate reactions in the skin of experimental animals provoked by antibody-antigen interaction. Progr Allergy 5:459-508, 1958

9. Boyden SV: The adsorption of proteins on erythrocytes treated with tannic acid and subsequent hemagglutination by antiprotein sera. J Exp Med 93:107-120, 1951 
10. Mills JA: The immunologic significance of antigen-induced lymphocyte transformation in vitro. J Immunol 97:239-247, 1966

11. Plotkin GR, Isselbacher KJ: Secondary disaccharidase deficiency in aduit celiac disease (nontropical sprue) and other malabsorption states. N Engl J Med 271:1033-1037, 1964

12. Messer M, Anderson CM, Townley RRW: Peptidase activity of biopsies of the duodenal mucosa of children with and without celiac disease. Clin Chim Acta 6:768-775, 1961

13. Pittman FE, Pollitt RJ: Studies of jejunal mucosal digestion of peptic-trypsin digests of wheat protein in coeliac disease. Gut 7:368-371, 1966

14. Weijers HA, Van de Kamer JH: Celiac disease. VI. A rapid method to test wheat sensitivity. Acta Paediat 44:536-540, 1955

15. Alvey C, Anderson CM, Freeman M: Wheat gluten and coeliac disease. Arch Dis Child $32: 434-437,1957$

16. Krainich HG, Debojin F, Gautier E, et al: Additional research on the injurious effect of wheat flour in celiac disease: I. Acute gliadin reaction (gliadin shock). Helv Paediat Acta 13:432, 1958

17. French $A B$ : (1969) Lnpublished observations

18. Lepore $\mathrm{MJ}$ : Long-term or maintenance adrenal steroid therapy in nontropical sprue. Am J Med $25: 381-390,1958$

19. Kivel RM, Kearns DH, Liebowitz D: Significance of antibodies to dietary proteins in the serums of patients with nontropical sprue. N Engl J Med 271:769-772, 1964
20. Hobbs JR, Hepner GW: Deficiency of $8 \mathrm{M}$ globulin in celiac disease. Lancet 1:217-220, 1968

21. Asquith P, Thompson RA, Cooke WT: Serum immunoglobulins in adult celiac disease. Lancet 2:129-131, 1969

22. Hobbs JR, Hepner GW, Douglas AP, et al: Immunological mystery of coeliac disease. Lancet 2:649-650, 1969

23. Bletcher TE, Brzechwa-Ajdukiewicz $A$, McCarthy CF, et al: Serum immunoglobulins and lymphocyte transformation studies in coeliac disease. Gut 10:57-62, 1969

24. Rubin W, Fanci AS, Sleisenger MH, et al: Immunofluorescent studies in adults with celiac disease. J Clin Invest 44:475-485, 1965

25. Katz J, Kantor FS, Herskovic T: Intestinal antibody to wheat fractions in celiac disease. Ann Intern Med 69:1149-1153, 1968

26. Huizenga KA, Wollaeger EE, Green PA, et al Serum globulin deficiency in nontropical sprue, with report of two cases of acquired agammaglobulinemia. Am J Med 31:572-580, 1961

27. Ferguson A, Maxwell JD, Hutton MM, et al: Adult coeliac disease in hyposplenic patients. Lancet 1:163-164, 1970

28. Gough KR, Read AE, Naish JM: Intestinal reticulosis as a complication of idiopathic steatorrhea. Gut 3:232-239, 1962

29. Austad WI, Cornes JS, Gough KR, et al: Steatorrhea and malignant lymphoma: the relationship of malignant tumors of lymphoid tissue and celiac disease. Am J Dig Dis 12:475-490. 1967 